\title{
Aplikasi Pre-Heating dan Edible Coating untuk Peningkatan Kualitas Keripik Kentang
}

\author{
Application of Pre-Heating and Edible Coating to Improve \\ the Quality Potato Chips
}

\begin{abstract}
Adolf Jan Nexson Parhusip*, Aileen Neysha, Lincoln Halim, dan Fernando Ogyen Iwantoro
Program Studi Teknologi Pangan, Fakultas Sains dan Teknologi Universitas Pelita Harapan, Tangerang

Abstract. This study aimed to improve the crispness and to reduce oil absorption in potato chips. Potato chips crispness was improved by applying pre-heating, namely boiling and steaming before frying, while oil absorption was reduced by adding acacia gum as an edible coating. Boiling and steaming was conducted at $100^{\circ} \mathrm{C}$ for 0, 2, 3, 4, 5, and 6 minutes. Acacia gum (0, 3, 4, 5, and 6\%) and calcium chloride (0, 0.5, and 1\%) were added in the formulation. Boiling for 4 minutes yielded hardness of $384.902 \pm 25.10 \mathrm{~g}$, moisture content of $3.02 \pm 0.07 \%$, crispness score of $5.04 \pm 0.60$ (crispy), and overall hedonic score of $5.10 \pm 1.43$ (somewhat like). Further process by adding acacia gum $5 \%$ and calcium chloride $1 \%$ yielded potato chips with fat content of $28.01 \pm 1.56 \%$, oil absorption ratio of $0.32 \pm 0.03$, moisture content of $1.07 \pm 0.78 \%$, and hardness level of $411.111 \pm 25.32 \mathrm{~g}$. The products recuded oil absorption during frying up to $41.81 \pm 5.86 \%$.
\end{abstract}

Keywords: acacia gum, potato chips, pre-heating, edible coating

\begin{abstract}
Abstrak. Penelitian ini bertujuan untuk meningkatkan kerenyahan dan menurunkan penyerapan minyak pada keripik kentang. Keripik kentang dapat meningkat kerenyahannya dengan metode pre-heating yaitu perebusan dan pengukusan sebelum digoreng. Penyerapan minyak dapat diturunkan dengan penambahan acacia gum sebagai edible coating. Perebusan dan pengukusan dilakukan pada $100^{\circ} \mathrm{C}$ selama $0,2,3,4$, 5, dan 6 menit. Acacia gum yang ditambahkan sebanyak 0, 3, 4, 5, dan $6 \%$ pada konsentrasi kalsium klorida 0, 0.5, dan 1\%. Perebusan selama 4 menit menghasilkan kripik kentang dengan kekeran sebesar $384.902 \pm 25.10 \mathrm{~g}$, kadar air sebesar 3.02 $\pm 0.07 \%$, skor kerenyahan sebesar 5.04 \pm 0.60 (renyah), dan skor hedonik secara keseluruhan sebesar 5.10 1.43 (agak suka). Proses selanjutnya dengan penambahan acacia gum 5\% dan kalsium klorida $1 \%$ menghasilkan kripik kentang dengan kadar lemak sebesar 28.01 $\pm 1.56 \%$, rasio penyerapan minyak sebesar $0.32 \pm 0.03$, kadar air sebesar $1.07 \pm 0.78 \%$, dan tingkat kekerasan sebesar $411.111 \pm 25.32 \mathrm{~g}$. Produk mengalami penurunan penyerapan minyak selama penggorengan hingga $41.81 \pm 5.86 \%$.
\end{abstract}

Kata kunci: acacia gum, keripik kentang, pre-heating, edible coating

Aplikasi Praktis. Hasil penelitian memberikan informasi bahwa perebusan selama 4 menit sebelum
kentang digoreng meningkatkan kerenyahan keripik kentang sebesar $26 \%$. Perendaman keripik kentang
pada larutan 5\% acacia gum sebagai edible coating mengurangi pemakaian minyak hingga $41.81 \%$ pada
saat penggorengan. Dengan demikian maka usulan perbaikan proses dapat dilakukan untuk peningkatan
mutu kripik kentang baik pada usaha skala mikro maupun pada industri besar.

\section{PENDAHULUAN}

Indonesia merupakan negara yang subur dan baik untuk perkembangan budidaya kentang yang saat ini menjadi yang terbesar di Asia Tenggara. Menurut Direktorat Jenderal Hortikultura (2019), produksi kentang di Indonesia meningkat dari 1.16 juta ton (tahun 2017) menjadi 1.28 juta ton (tahun 2018). Kentang (Solanum tuberosum L.) merupakan jenis umbi-umbian yang biasa digunakan sebagai sumber karbohidrat dan paling efisien dalam mengkonversikan sumber daya alam serta tenaga kerja (Asgar 2013).
Dua varietas kentang yang paling banyak digunakan yaitu varietas atlantik dan granola. Varietas atlantik adalah kentang yang umum digunakan untuk membuat keripik kentang karena umbinya putih, kadar air rendah, kadar gula rendah, dan kadar pati yang tinggi sehingga dapat menghasilkan hasil keripik kentang berkualitas baik. Varietas atlantik memiliki kelemahan yaitu produksinya rendah di Indonesia maka untuk mencukupi kebutuhan industri perlu impor (Prahardini dan Pratomo 2004). Produksi kentang granola cukup tinggi, yaitu sebesar 30-35 ton/ha (Fajiarningsih 2013). Kentang granola merupakan kentang dengan kandungan pati rendah (16-18\%) dan kandungan air tinggi (lebih dari 80\%). Kentang jenis ini lebih cocok diolah menjadi kentang

Korespondensi: adolf.parhusip@uph.edu 
rebus karena pori-porinya sulit mengeluarkan air pada saat pemasakan.

Kalsium klorida dapat diaplikasikan pada produk olahan untuk mempertahankan tekstur dari buah dan sayuran. Suhu panas pada proses pemasakan dapat menurunkan kualitas teksur pada produk makanan. Ini dapat terjadi karena adanya pergantian permebilitas sel, pektin, dan efek gula pada perendaman. Kalsium sebagai bahan perendam dapat meningkatkan kerenyahan produk seperti keripik kentang (Arum et al. 2021).

Kerenyahan dari keripik merupakan karakteristik yang penting dari keripik kentang (Thanatuksorn et al. 2018). Keripik kentang adalah makanan ringan yang lebih mengutamakan kenampakan dan tekstur daripada kandungan gizi, sehingga sebaiknya diarahkan dan difokuskan pada peningkatan tekstur kerenyahan dan perbaikan warna supaya lebih menarik (Wibowo et al. 2006). Metode pre-heating seperti perebusan dan pengukusan sebelum penggorengan masih belum populer tetapi berpotensi dapat meningkatkan kerenyahan keripik (Grizotto dan De Menezes 2020).

Makanan yang digoreng memiliki tekstur renyah dan rasa yang menyenangkan, dapat menyebabkan rasa kenyang dengan harga terjangkau, dan produk ini yang mudah didapat (Listianti dan Ediati 2019). Masalah kesehatan terkait dengan kandungan lemak dan keberadaan akrilamida pada keripik kentang menuntut untuk dicari alternatif yang mengarah pada makanan goreng yang lebih sehat dan lebih aman (Trujillo-Agudelo et al. 2019). Saat ini, salah satu alternatif yang paling menonjol adalah penggunaan edible coating yang merupakan matriks bersambung dan tipis yang terstruktur di sekitar makanan yang umumnya diperoleh dengan merendam makanan dalam larutan pelapis (TorresGonzález et al. 2017; Valdés et al. 2015). Edible coating merupakan lapisan tipis yang dapat dimakan untuk melapisi suatu makanan sebagai penghalang perpindahan massa dan meningkatkan penanganan suatu makanan agar dapat terjaga kualitasnya, mencegah pembusukan, memperpanjang masa simpan, dan melindungi sifat sensorik makanan (Beals 2019; Caetano et al. 2017). Edible coating berperan untuk melindungi produk dari kerusakan mekanis, fisik, kimia (Mousa 2018), dan dari aktivitas mikrobiologis (Falguera 2011).

Tujuan penelitian ini adalah memperbaiki kualitas dan kerenyahan keripik kentang serta mengurangi penyerapan minyak pada keripik kentang varietas granola dengan menggunakan metode pre-heating yang tepat dan penggunaan konsentrasi larutan edible coating yang terbaik.

\section{BAHAN DAN METODE}

\section{Bahan}

Umbi kentang (Solanum tuberosum L.) yang digunakan adalah varietas granola dengan berat setiap butirnya 80-100 g, berbentuk bulat lonjong dan diameter 6 $\mathrm{cm}$. Umbi kentang berumur tiga bulan dan berasal dari petani Citayam Bogor. Bahan lainnya adalah acacia gum (indochem), kalsium klorida (indochem), air mineral, minyak goreng kelapa sawit, n-heksana, dan akuades.

Alat yang digunakan dalam penelitian neraca analitik Sartorius BP $221 \mathrm{~S}$, timbangan meja Mettler Toledo PL3002, deep fat fryer Fritaeco Restomart 8290, pisau, chromameter Konica Minolta CR-400, texture analyzer (Stable Micro System TA.XT. Plus), oven Memmert Une 200-800, vakum rotavapor (Heidolph), desikator (Duran), $\mathrm{pH}$ meter (Metrohm), dan alat pemasak dan alat gelas.

\section{Perlakuan pre-heating (Mandei dan Nuryadi 2017)}

Perlakuan pre-heating dilakukan untuk mendapatkan waktu terbaik agar diperoleh kerenyahan keripik kentang. Penerapan pre-heating yang dilakukan adalah dengan perebusan atau pengukusan pada suhu $100^{\circ} \mathrm{C}$ selama $0,2,3,4,5$, dan 6 menit.

\section{Pembuatan keripik kentang (Mandei dan Nuryadi 2017)}

Pembuatan keripik kentang, diawali dengan memasukkan kentang ke dalam mesin pencuci kentang supaya kulit bersih dari kotoran. Kemudian kentang diiris tipis menggunakan alat pengiris kentang. Setelah itu irisan kentang dibagi menjadi sepuluh perlakuan yaitu perebusan dan pengukusan dengan suhu $100^{\circ} \mathrm{C}$ pada waktu 2, 3, 4, 5, dan 6 menit. Irisan kentang digoreng secara deep fryer dengan menggunakan minyak kelapa sawit dengan suhu $180^{\circ} \mathrm{C}$ selama 3 menit. Kemudian keripik kentang ditiriskan menggunakan spinner.

\section{Perlakuan pemberian edible coating (Damto dan Chala 2019)}

Pada tahap ini keripik kentang dengan perlakuan terbaik dari perlakuan pre-heating dicelupkan ke dalam larutan edible coating berupa acacia gum dengan konsentrasi $0,3,4,5$, dan $6 \%$, kemudian ditambahkan kalsium klorida dengan konsentrasi $0,0.5$, dan $1 \%$.

\section{Pembuatan larutan edible coating dengan penam- bahan kalsium klorida (Mousa 2018)}

Pertama-tama dilarutkan 2.5 dan $5 \mathrm{~g} \mathrm{CaCl}_{2}$ dalam $500 \mathrm{~mL}$ akuades untuk mendapatkan konsentrasi $\mathrm{CaCl}_{2}$ 0.5 dan $1 \%$. Kemudian dilarutkan $15 \mathrm{~g}$ acacia gum dalam $500 \mathrm{~mL}$ akuades untuk mendapatkan konsentrasi acacia gum $2 \%$ (b/v), kemudian ke dalam larutan tersebut ditambahkan 3\% sorbitol dan diaduk sampai larut. Perlakuan ini dilakukan juga pada pembuatan konsentrasi acacia gum 4, 5, dan 6\% dengan melarutkan acacia gum masing-masing sebanyak 20, 25, dan $60 \mathrm{~g}$ pada $500 \mathrm{~mL}$ akuades, dan ditambah sorbitol $3 \%$.

\section{Analisis}

Pada penelitian ini dilakukan analisis kadar air (dry basis) (AOAC 2005), kadar abu (AOAC 2005), kadar lemak (AOAC 2005), penyerapan minyak (Garcia et al. 
2002), rasio penyerapan minyak (Magre et al. 2019), kadar pati (AOAC 2005), kadar amilosa (AOAC 2005), kadar amilopektin (AOAC 2005), uji skoring, dan uji hedonik (Angor 2016) dengan panelis tidak terlatih berjumlah 70 orang.

Analisis tingkat kecerahan keripik kentang dilakukan pada hasil keripik kentang dengan penambahan acacia gum dan kalsium klorida. Nilai kecerahan didapatkan dengan mengukur tingkat kecerahan permukaan keripik kentang yang sudah ditumbuk sampai halus. Analisis tingkat kecerahan dilakukan dengan alat Minolta CR-300 Chromameter.

Analisis untuk menguji tingkat kekerasan produk dilakukan dengan menggunakan Texture Analyzer jenis TAXT-2 (Hua et al. 2015). Pengaturan kecepatan probe menyentuh sampel untuk melihat nilai output hasil kekerasan adalah $2 \mathrm{~mm} /$ detik, jarak awal antara probe dan sampel yang diuji adalah $52 \mathrm{~mm}$ dengan probe jenis Ottawa cell (A/OTC) $25 \mathrm{~kg}$. Nilai maksimum dari force dengan satuan $\mathrm{g}$ dicatat menjadi kekerasan, kecerahan (Minolta CR-300 Chroma Meter) (Chandra et al. 2014).

\section{Rancangan percobaan}

Penelitian pertama menggunakan Rancangan Acak Lengkap (RAL) dua faktor yaitu perebusan dan pengukusan dengan tiga kali pengulangan, sedangkan penelitian tahap kedua dengan satu faktor dengan dua kali ulangan. Pengujian statistik menggunakan analisis univariate dengan menggunakan software SPSS.

\section{HASIL DAN PEMBAHASAN}

\section{Kualitas keripik kentang dengan proses pre-heating}

\section{Kadar Air}

Gambar 1 menunjukkan kadar air keripik kentang dengan metode pre-heating. Metode pre-heating pada keripik kentang memiliki pengaruh signifikan $(p<0.05)$ terhadap waktu perebusan atau pengukusan. Keripik kentang dengan kadar air tertinggi sebesar $5.67 \pm 0.41 \%$ untuk metode pengukusan dengan waktu 2 menit dan yang terendah sebesar $3.02 \pm 0.07 \%$ untuk metode perebusan dengan waktu 4 menit. Persentase kadar air keripik kentang dengan metode pre-heating cenderung lebih rendah dibandingkan keripik kentang tanpa metode preheating. Hal ini terjadi karena pada proses pre-heating pati mengalami gelatinisasi yang menyebabkan adanya pembengkakan granula pati dan penyerapan air yang lebih banyak dibandingkan pati yang tidak mengalami proses gelatinisasi (Anugrahati et al. 2015). Hal ini berakibat ketika bahan digoreng dengan suhu $180^{\circ} \mathrm{C}$, granula pati yang mengalami proses gelatinisasi akan lebih cepat pecah dan air akan lebih cepat menguap (Damto dan Chala 2019).

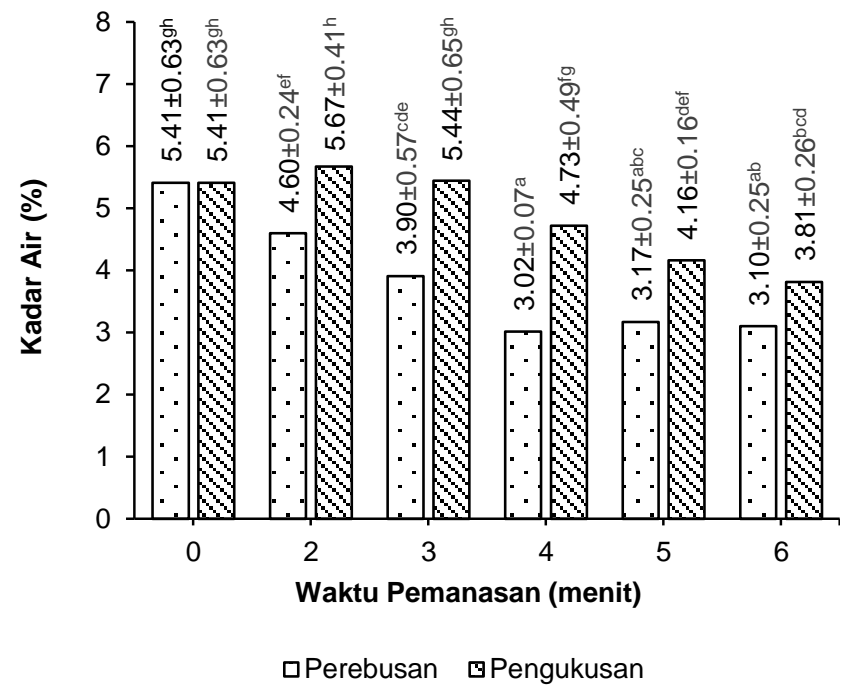

Gambar 1. Kadar air keripik kentang metode pre-heating

\section{Kecerahan (Lightness)}

Gambar 2 menunjukkan nilai lightness keripik kentang dengan metode pre-heating. Tidak terdapat interaksi dari metode pre-heating dan waktu pemanasan terhadap lightness keripik kentang ( $>00.05)$. Namun terdapat perbedaan signifikan dari metode pre-heating yang digunakan yaitu perebusan, pengukusan, dan waktu pemanasan yang digunakan $(\mathrm{p}<0.05)$. Lightness keripik kentang yang terendah dimiliki oleh keripik kentang tanpa metode pre-heating sebesar $29.33 \pm 0.21$ dan lightness keripik kentang yang tertinggi dimiliki oleh keripik kentang dengan metode perebusan dengan waktu 6 menit sebesar $45.73 \pm 0.77$. Keripik kentang dengan metode pre-heating menghasilkan nilai lightness yang lebih besar daripada keripik kentang tanpa metode preheating karena adanya difusi sukrosa ke air pada proses pre-heating (Rosanna et al. 2015). Pre-heating menonaktifkan dan meningkatkan warna serta mengurangi penyerapan minyak akibat dari gelatinisasi pati (Damto dan Chala 2019). Pada saat penggorengan pada suhu yang tinggi, kentang mengalami reaksi kecoklatan enzimatis yang disebabkan oleh banyaknya gula pereduksi pada kentang. Semakin banyak gula maka warna kentang akan semakin cokelat gelap atau mengalami reaksi Maillard (Rahmawati dan Nisa 2015).

\section{Tingkat kekerasan (Hardness)}

Gambar 3 menunjukkan nilai hardness keripik kentang dengan metode pre-heating. Terdapat interaksi dari metode pre-heating dan waktu pemanasan yang signifikan ( $\mathrm{p}<0.05)$ terhadap hardness keripik kentang. Hardness keripik kentang dengan tanpa metode pre-heating memiliki nilai hardness yang paling tinggi sebesar $523.983 \pm 24.67 \mathrm{~g}$, sedangkan nilai hardness yang paling kecil didapatkan oleh keripik kentang dengan metode

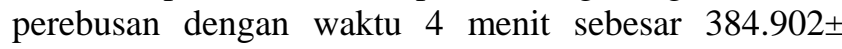
25.18 g. Nilai hardness yang lebih rendah menunjukkan peningkatan kerenyahan dari suatu produk karena gaya yang diperlukan untuk menghancurkan produk lebih rendah (Rosanna et al. 2015). Kadar air produk yang lebih rendah berhubungan dengan tekstur yang lebih 
renyah karena ketika penggorengan produk akan kehilangan air dari dehidrasi yang menghasilkan crust sehingga produk akan lebih renyah (Kurek et al. 2017).

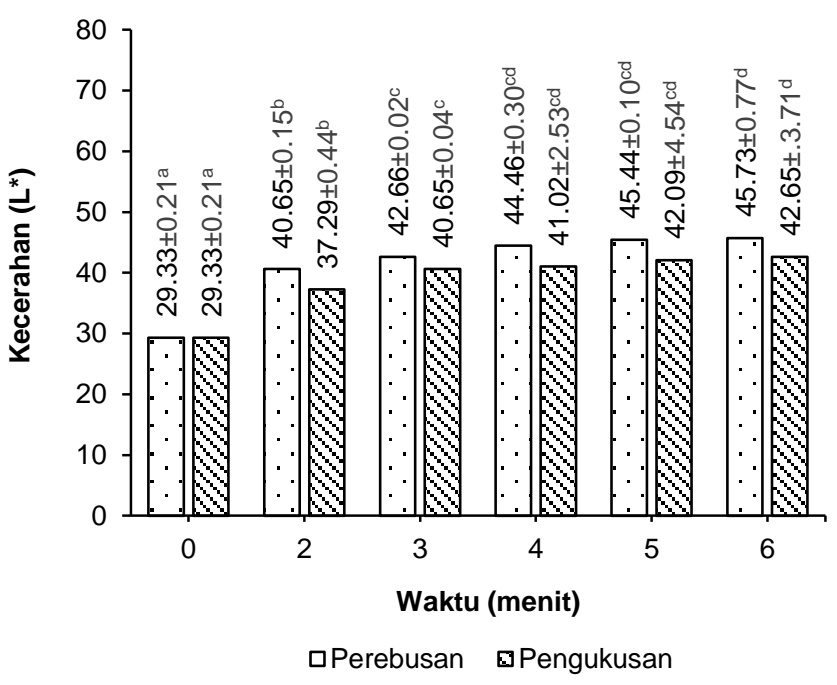

Gambar 2. Nilai lightness keripik kentang dengan metode pre-heating

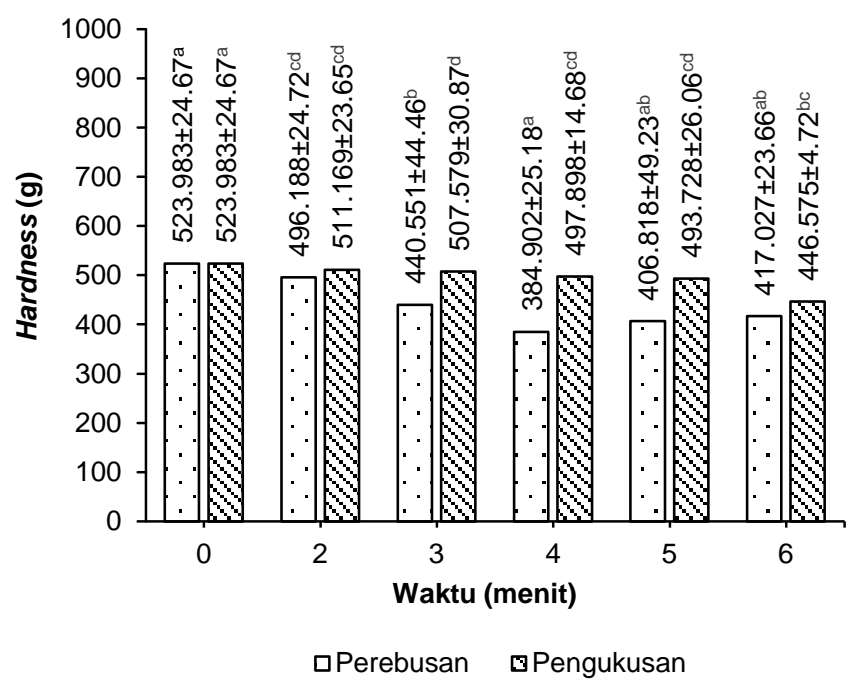

Gambar 3. Nilai hardness keripik kentang dengan metode pre-heating

\section{Skoring warna}

Gambar 4 menunjukkan hasil skoring warna keripik kentang metode pre-heating. Terdapat pengaruh signifikan $(\mathrm{p}<0.05)$ dari interaksi metode pre-heating dan waktu pemanasan terhadap hasil uji skoring warna keripik kentang. Hasil uji skoring warna menunjukkan bahwa keripik kentang yang dilakukan metode preheating mempunyai warna yang lebih cerah dibandingkan yang tidak mengalami metode pre-heating. Semakin lama waktu perebusan yang dilakukan juga semakin tinggi nilai kecerahan yang dihasilkan.

\section{Skoring kerenyahan}

Gambar 5 menunjukkan hasil skoring kerenyahan keripik kentang metode pre-heating. Terdapat pengaruh signifikan $(\mathrm{p}<0.05)$ dari interaksi metode pre-heating dan waktu pemanasan terhadap hasil uji skoring warna keripik kentang. Hasil uji skoring kerenyahan menunjukkan bahwa keripik kentang yang dilakukan preheating dengan perebusan selama 4 menit mendapatkan nilai skala kerenyahan yang paling tinggi sama dengan hasil penelitian Mandei dan Nuryadi (2017) yang menunjukkan keripik kentang dengan perebusan di suhu $80^{\circ} \mathrm{C}$ selama 5 menit mendapatkan hasil yang renyah. Pada Gambar 5 juga dapat dilihat bahwa nilai skala kerenyahan keripik kentang dengan metode perebusan lebih besar daripada dengan metode pengukusan.

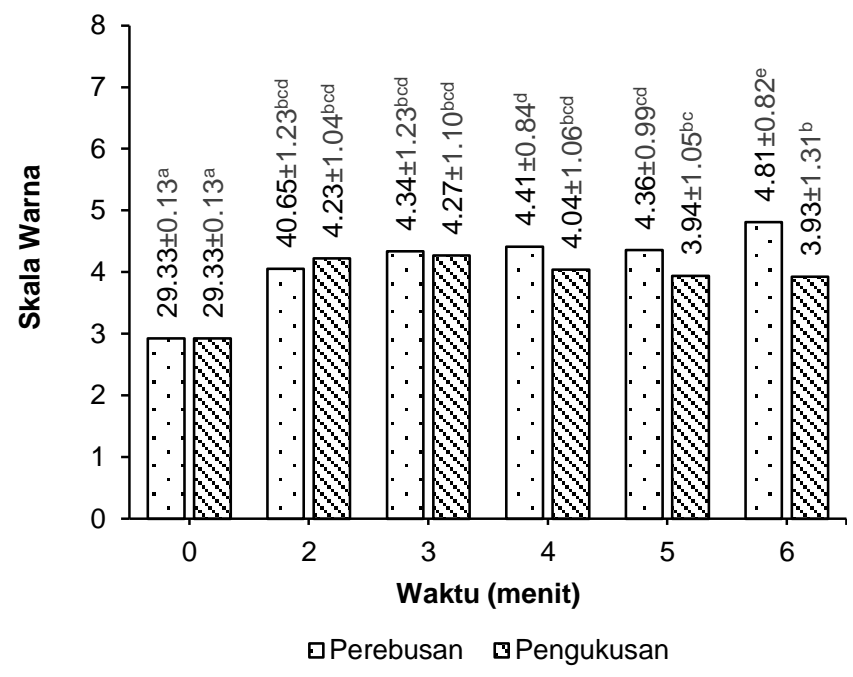

Gambar 4. Uji skoring warna keripik kentang dengan metode pre-heating

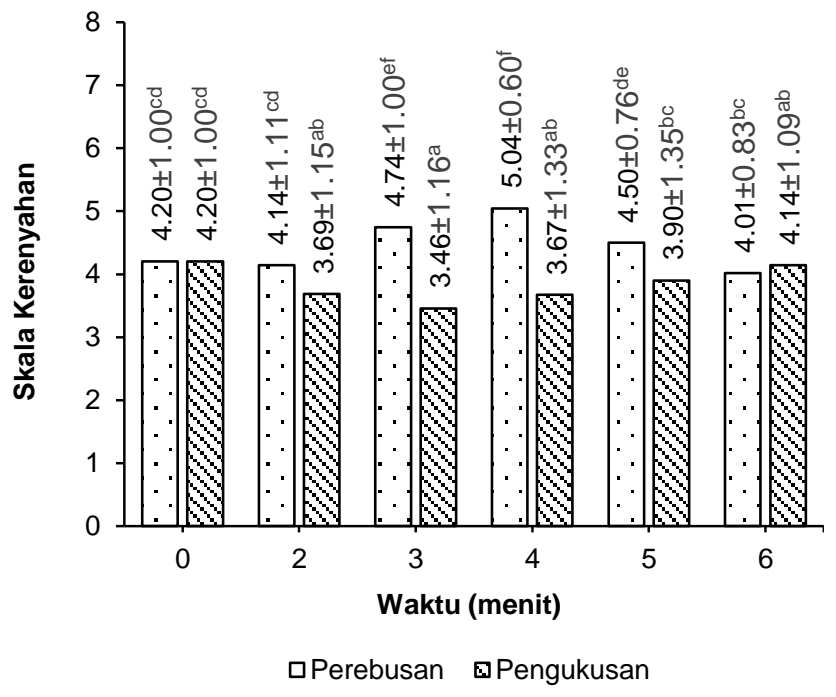

Gambar 5. Kerenyahan keripik kentang dengan metode pre-heating

\section{Hedonik warna}

Gambar 6 menunjukkan hasil hedonik warna keripik kentang metode pre-heating. Terdapat pengaruh signifikan $(\mathrm{p}<0,05)$ dari interaksi metode pre-heating dan waktu pemanasan terhadap hasil uji hedonik warna keripik kentang. Hasil uji hedonik warna menunjukkan bahwa panelis lebih menyukai warna keripik kentang 
yang dilakukan pre-heating dibandingkan keripik kentang tanpa pre-heating.

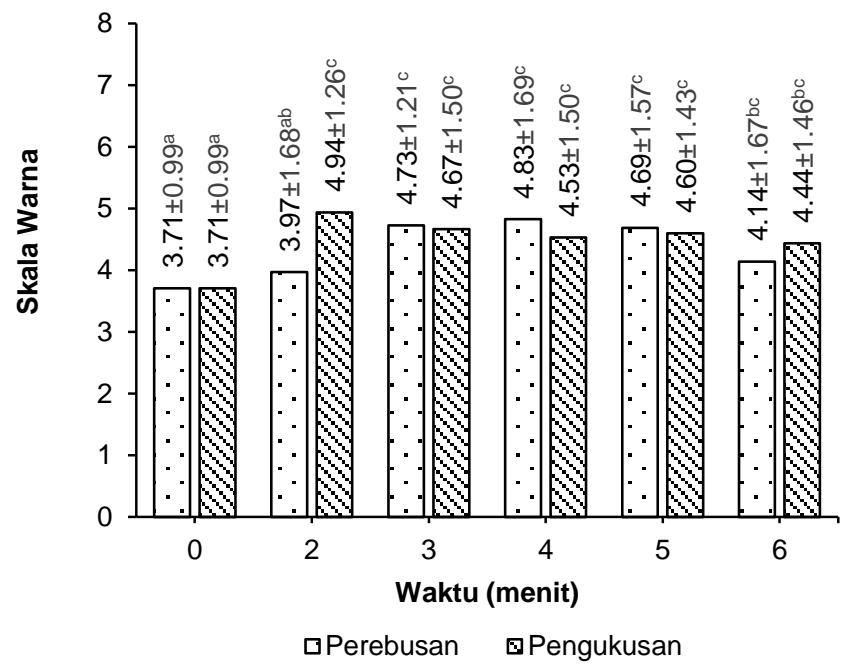

Gambar 6. Warna keripik kentang dengan metode preheating

\section{Hedonik kerenyahan}

Gambar 7 menunjukkan hasil hedonik kerenyahan keripik kentang metode pre-heating. terdapat pengaruh signifikan $(\mathrm{p}<0,05)$ dari interaksi metode pre-heating dan waktu pemanasan terhadap hasil uji hedonik kerenyahan keripik kentang. Hasil uji hedonik kerenyahan menunjukkan dan panelis lebih menyukai kerenyahan keripik kentang yang telah dilakukan pre-heating terutama pada metode perebusan dibandingkan dengan metode pengukusan.

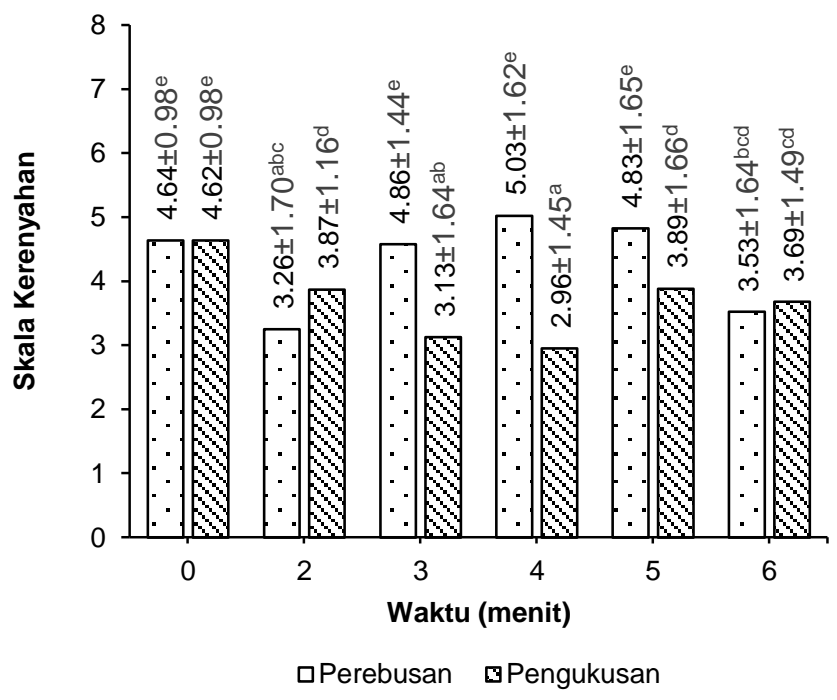

Gambar 7. Kerenyahan keripik kentang dengan metode pre-heating

\section{Hedonik keseluruhan}

Hasil uji hedonik terhadap kripik kentang keseluruhan menunjukkan beda nyata $(\mathrm{p}<0.05)$ bahwa panelis cenderung lebih menyukai keseluruhan keripik kentang yang dilakukan pre-heating terutama pada metode pere- busan dibandingkan dengan metode pengukusan (Gambar 8).

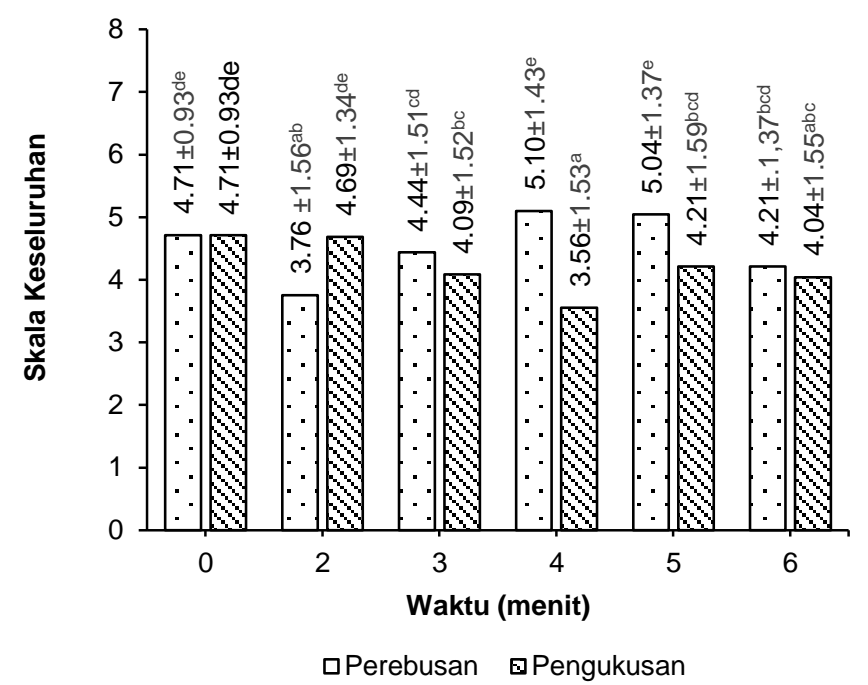

Gambar 8. Kesukaan keseluruhan keripik kentang dengan metode pre-heating

\section{Kualitas keripik kentang dengan edible coating dan penambahan kalsium klorida}

\section{Kadar air}

Gambar 9 menunjukkan kadar air keripik kentang dengan menggunakan edible coating dan penambahan kalsium klorida. Terdapat interaksi signifikan $(\mathrm{p}<0.05)$ dari penambahan konsentrasi acacia gum dan kalsium klorida pada kadar air keripik kentang. Keripik kentang dengan tanpa penambahan acacia gum kalsium klorida (kontrol) memiliki kadar air yang paling tinggi yaitu sebesar $2.17 \pm 0.25 \%$. Hal ini didukung oleh penelitian Haryanti et al. (2015) yang menyatakan bahwa perendaman kalsium klorida dan penggunaan edible coating dapat meningkatkan kerenyahan dan menurunkan jumlah kadar air pada produk. Hasil kadar air keripik kentang dengan penambahan acacia gum dan kalsium klorida masih di bawah maksimum kadar air keripik kentang (BSN 1996; USDA 2019).

Persentase kadar air pada keripik kentang menurun seiring dengan penambahan konsentrasi acacia gum dan kalsium klorida. Hal ini dapat terjadi karena pada perlakuan pemberian edible coating, pati kentang sudah tergelatinisasi terlebih dahulu pada saat proses pre-heating yang menyebabkan air lebih cepat menguap (Rosanna et al. 2015). Penggunaan sorbitol sebagai plastisizer pada larutan edible coating dapat mengurangi daya serap air dibandingkan gliserol (Sanyang et al. 2019).

\section{Kadar $a b u$}

Gambar 10 menunjukkan kadar abu keripik kentang dengan menggunakan edible coating dan penambahan kalsium klorida. Terdapat interaksi signifikan $(\mathrm{p}<0.05)$ dari penambahan konsentrasi acacia gum dan kalsium klorida pada kadar abu keripik kentang. Kentang kontrol memiliki kadar abu paling kecil yaitu sebesar $0.43 \pm$ $0.05 \%$. Kadar abu dengan nilai tertinggi didapatkan oleh 
keripik kentang dengan penambahan acacia gum $6 \%$ dan kalsium klorida $1 \%$ yaitu sebesar $1.42 \pm 0.15 \%$. Kadar abu dengan nilai tertinggi didapatkan oleh keripik kentang dengan penambahan acacia gum $6 \%$ dan kalsium klorida $1 \%$ yaitu sebesar $1.42 \pm 0.15 \%$.

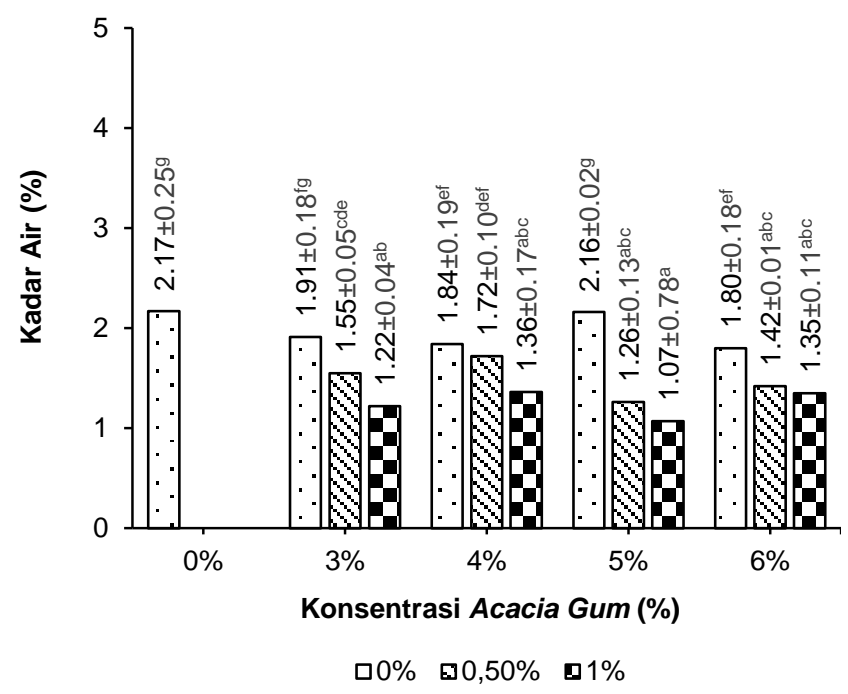

Gambar 9. Kadar air keripik kentang menggunakan edible coating dan kalsium klorida

Semakin meningkatnya konsentrasi acacia gum dan kalsium klorida terhadap keripik kentang, maka semakin tinggi juga kadar abu yang dihasilkan (Gambar 10). Hal ini disebabkan oleh ion kalsium yang berpenetrasi masuk ke dalam jaringan kentang yang menyebabkan meningkatnya kandungan mineral pada keripik kentang (Mandei dan Nuryadi 2017).

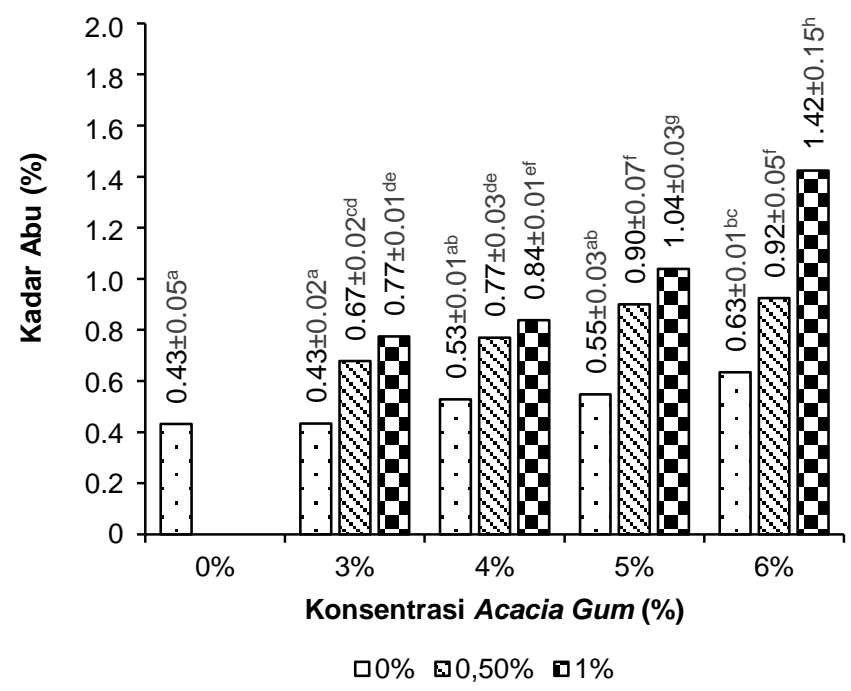

Gambar 10. Kadar abu keripik kentang dengan menggunakan edible coating dan penambahan kalsium klorida

Kadar lemak, penyerapan minyak, dan rasio penyerapan minyak

Gambar 11 menunjukkan kadar lemak dan penyerapan minyak keripik kentang dengan menggunakan edible coating dan penambahan kalsium klorida. Gambar 12 menunjukkan rasio penyerapan minyak. Ter- dapat perbedaan signifikan $(\mathrm{p}<0.05)$ dari penambahan konsentrasi acacia gum sebagai edible coating terhadap kadar lemak dan penyerapan minyak keripik kentang. Keripik kentang dengan penambahan acacia gum 5\% dan $6 \%$ mempunyai persentase kadar lemak yang paling rendah sebesar masing-masing $28.01 \pm 1.56$ dan $28.20 \pm$ $1.77 \%$. Persentase penyerapan minyak yang paling kecil juga didapatkan oleh perlakuan keripik kentang dengan penambahan acacia gum 5\% dan $6 \%$ yaitu sebesar $41.81 \pm 5.86$ dan $-41.42 \pm 3,68 \%$ diikuti dengan rasio penyerapan minyak yang rendah yaitu sebesar $0.32 \pm 0.03$ dan 0.32 \pm 0.02 . Semakin bertambahnya konsentrasi acacia gum, maka semakin rendah kadar lemak yang dihasilkan dari keripik kentang. Hal ini sama dengan hasil penelitian Wibowo et al. (2018) yang menyatakan bahwa keripik kentang dengan penggunaan acacia gum sebagai edible coating mempunyai kadar lemak yang paling rendah. Menurunnya kadar lemak pada keripik kentang terjadi pada saat pencelupan kentang pada larutan edible coating yang menyebabkan terjadinya pembentukan gel pada saat awal penggorengan (Ajo 2017; Thanatuksorn 2018). Hal ini berhubungan dengan karakteristik sekunder dari hidrokoloid yang dapat membentuk lapisan gel saat adanya gelasi termal pada hidrokoloid (Wibowo et al. 2019).

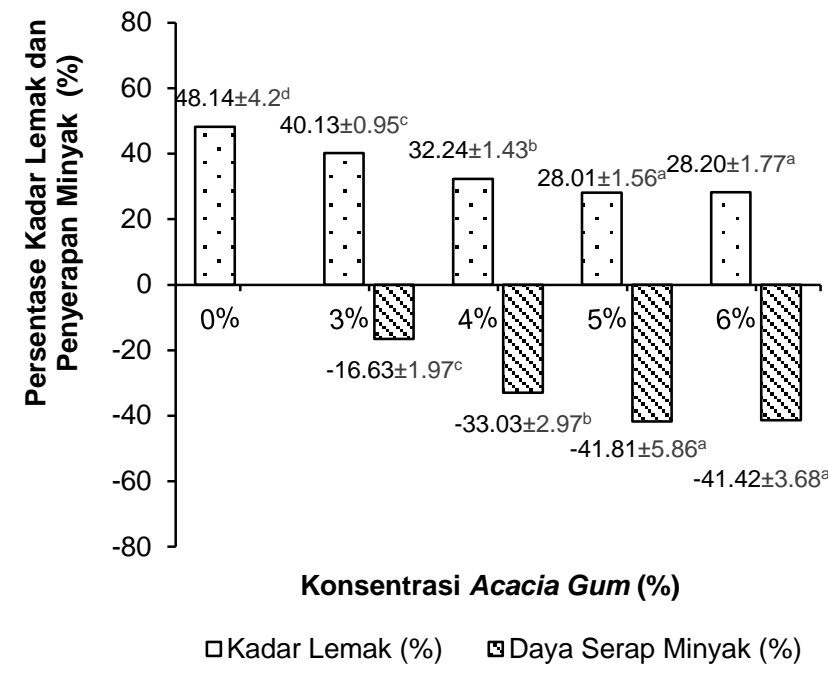

Gambar 11. Kadar lemak dan penyerapan minyak keripik kentang dengan menggunakan edible coating dan penambahan kalsium klorida

\section{Kecerahan}

Gambar 13 menunjukkan kecerahan keripik kentang dengan menggunakan edible coating dan penambahan kalsium klorida. Terdapat perbedaan signifikan interaksi dari konsentrasi acacia gum dan kalsium klorida terhadap lightness keripik kentang $(\mathrm{p}<0.05)$. Berdasarkan uji lanjut, lightness keripik kentang yang memiliki nilai tertinggi adalah keripik kentang dengan tanpa penambahan acacia gum dan kalsium klorida (45.19 \pm 0.35$)$. Semakin bertambahnya konsentrasi acacia gum dan kalsium klorida maka nilai lightness keripik kentang semakin kecil. Hal ini disebabkan karena warna abu-abu 
muda yang dihasilkan dari larutan edible coating acacia gum (Maity et al. 2015).

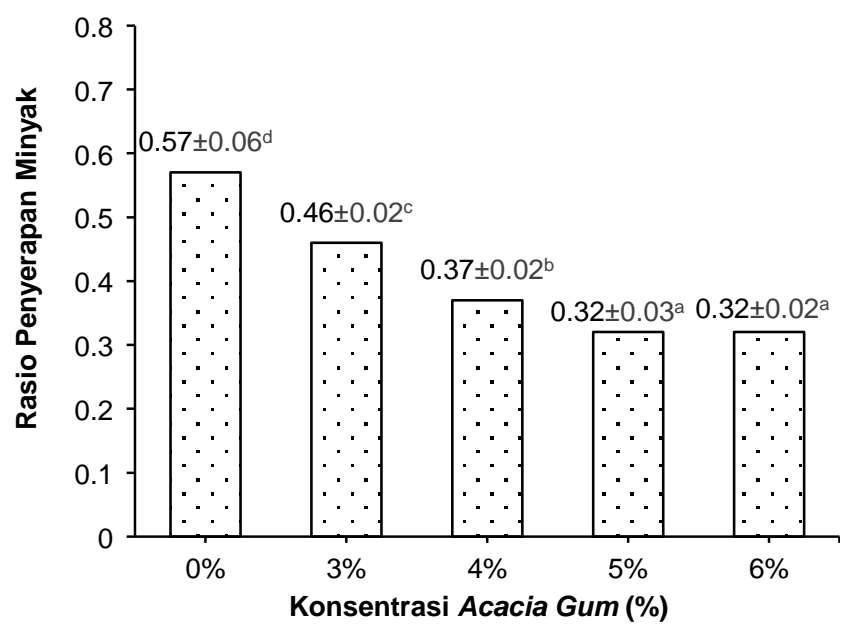

口Rasio Penyerapan (Ur)

Gambar 12. Rasio penyerapan minyak keripik kentang dengan menggunakan edible coating

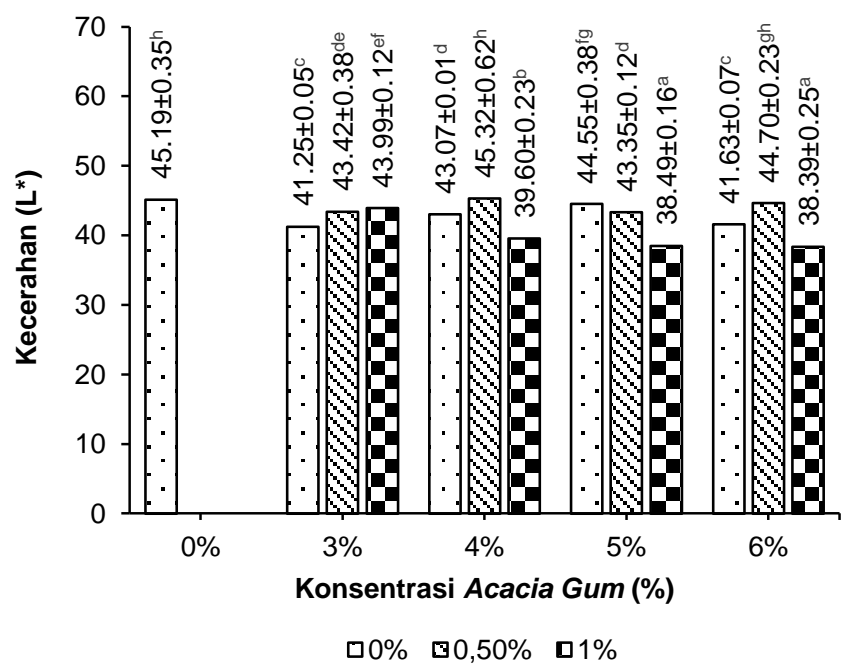

Gambar 13. Kecerahan keripik kentang dengan menggunakan edible coating dan penambahan kalsium klorida

\section{Tingkat kekerasan (Hardness)}

Gambar 14 menunjukkan kekerasan keripik kentang dengan menggunakan edible coating dan penambahan kalsium klorida. Tidak terdapat interaksi dari konsentrasi acacia gum dan kalsium klorida terhadap hardness keripik kentang ( $>00.05)$. Namun terdapat perbedaan signifikan dari penambahan konsentrasi acacia gum dan penambahan konsentrasi kalsium klorida terhadap hardness keripik kentang $(\mathrm{p}<0.05)$. Nilai hardness keripik kentang semakin menurun seiring bertambahnya konsentrasi kalsium klorida pada keripik kentang. Hal ini terjadi oleh terbentuknya ikatan kalsium dengan pektin, sehingga kentang mempunyai jaringan yang kuat untuk menghambat proses penguapan air dan mempercepat pembentukan crust yang berdampak meningkatnya kere- nyahan dari keripik kentang (Mandei dan Nuryadi 2017).

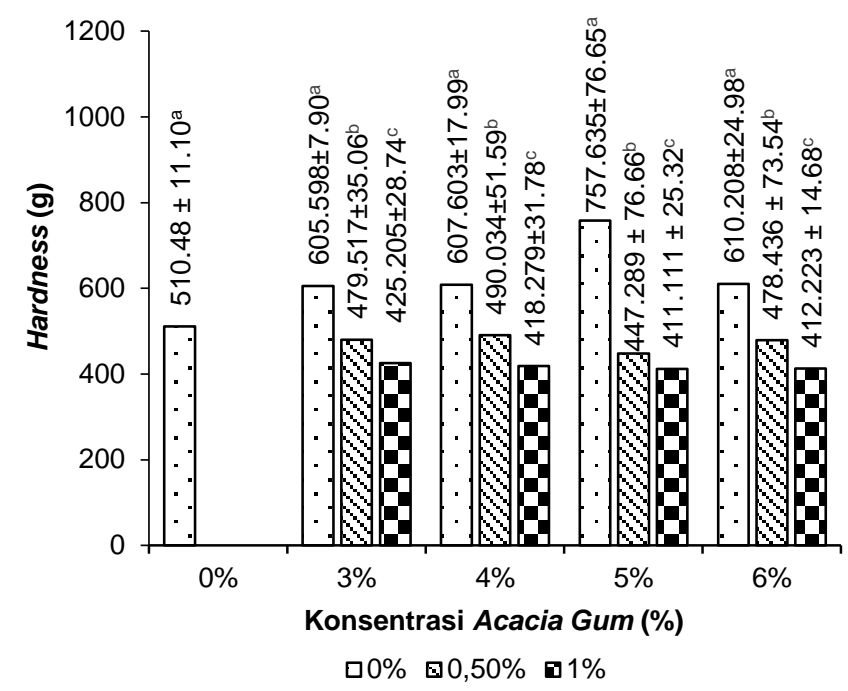

Gambar 14. Hardness keripik kentang dengan menggunakan edible coating dan penambahan kalsium klorida

\section{Kadar pati}

Tabel 1 menunjukkan kadar pati keripik kentang dengan menggunakan edible coating dan penambahan kalsium klorida. penambahan konsentrasi acacia gum berpengaruh secara signifikan $(\mathrm{p}<0.05)$ terhadap kadar pati pada keripik kentang. Hasil kadar pati tertinggi sebesar $45.69 \pm 0.10 \%$ untuk keripik kentang dengan penambahan acacia gum 0\% dan yang terendah sebesar $37.55 \pm 0.20 \%$ untuk keripik kentang dengan penambahan acacia gum 6\%. Kadar pati mempunyai peranan yang penting pada tekstur bahan pangan. Kadar pati yang tinggi akan menghasilkan tekstur yang lebih renyah (Listianti dan Ediati 2019). Abbot et al. (2005) juga menyatakan bahwa kerenyahan dapat disebabkan oleh perbedaan kandungan pati dan pektin yang dapat memengaruhi tekstur. Kadar pati yang menurun seiring penambahan konsentrasi acacia gum berhubungan dengan nilai kekerasan yang semakin meningkat (Tabel 1). Penurunan kadar pati dan peningkatan nilai kekerasan menandakan bahwa tekstur yang dihasilkan kurang renyah.

\section{Kadar amilosa}

Tabel 1 menunjukkan kadar amilosa keripik kentang dengan menggunakan edible coating dan penambahan kalsium klorida. penambahan konsentrasi acacia gum berpengaruh secara signifikan $(\mathrm{p}<0.05)$ terhadap kadar amilosa pada keripik kentang. Berdasarkan Tabel 1 didapatkan hasil kadar amilosa tertinggi sebesar 4.72 \pm $0.02 \%$ untuk keripik kentang dengan tanpa penambahan acacia gum dan yang terendah sebesar $3.97 \pm 0.02 \%$ untuk keripik kentang dengan penambahan acacia gum $6 \%$. Semakin besar konsentrasi acacia gum pada keripik kentang maka kadar amilosa yang dihasilkan akan semakin rendah. Keripik kentang dengan kadar amilosa yang tinggi berhubungan dengan nilai kekerasan yang 
tinggi (Tabel 1). Hal ini didukung oleh penelitian Sobukola et al. (2018) yang menjelaskan bahwa amilosa berperan penting dalam meningkatkan kekerasan sehingga hal ini menyebabkan meningkatknya konsistensi kekerasan pada produk dan terjadi penurunan kerenyahan saat kandungan amilosa yang tinggi. Produk dengan kadar amilosa yang tinggi memiliki tekstur yang lebih keras (Listianti dan Ediati 2019). Kandungan amilosa pada produk pangan sangat berpengaruh pada tingkat kerenyahan produk (Niken et al. 2013).

Tabel 1. Kadar pati, amilosa dan amilopektin keripik kentang dengan menggunakan edible coating

\begin{tabular}{cccc}
\hline $\begin{array}{c}\text { Konsentrasi } \\
\text { Acacia Gum } \\
(\%)\end{array}$ & $\begin{array}{c}\text { Kadar Pati } \\
(\%)\end{array}$ & $\begin{array}{c}\text { Kadar } \\
\text { Amilosa } \\
(\%)\end{array}$ & $\begin{array}{c}\text { Kadar } \\
\text { Amilopektin } \\
(\%)\end{array}$ \\
\hline 0 & $45.69 \pm 0.10^{\mathrm{d}}$ & $4.72 \pm 0.02^{\mathrm{e}}$ & $40.97 \pm 0.08^{\mathrm{c}}$ \\
3 & $38.96 \pm 0.10^{\mathrm{c}}$ & $4.46 \pm 0.02^{\mathrm{a}}$ & $34.49 \pm 0.12^{\mathrm{b}}$ \\
4 & $38.89 \pm 0.10^{\mathrm{c}}$ & $4.30 \pm 0.02^{\mathrm{c}}$ & $34.58 \pm 0.08^{\mathrm{b}}$ \\
5 & $38.29 \pm 0.15^{\mathrm{b}}$ & $4.22 \pm 0.03^{\mathrm{b}}$ & $34.06 \pm 0.18^{\mathrm{ab}}$ \\
6 & $37.55 \pm 0.20^{\mathrm{a}}$ & $3.97 \pm 0.02^{\mathrm{a}}$ & $33.58 \pm 0.18^{\mathrm{a}}$ \\
\hline
\end{tabular}

\section{Kadar amilopektin}

Tabel 1 menunjukkan kadar amilopektin keripik kentang dengan menggunakan edible coating dan penambahan kalsium klorida. Penambahan konsentrasi acacia gum berpengaruh secara signifikan $(\mathrm{p}<0.05)$ terhadap kadar amilopektin pada keripik kentang. Kadar amilopektin tertinggi $(40.97 \pm 0.08 \%)$ ditunjukkan pada keripik kentang tanpa penambahan acacia gum, sedangkan yang terendah sebesar $33.58 \pm 0.18 \%$ untuk keripik kentang dengan penambahan acacia gum $6 \%$.

Keripik kentang dengan penambahan acacia gum memiliki kadar amilopektin yang cenderung lebih rendah dibandingkan keripik kentang tanpa penambahan acacia gum (kontrol). Hal ini berhubungan dengan nilai kadar air (dry basis) pada keripik kentang kontrol lebih tinggi juga (Tabel 1). Semakin tinggi kadar amilopektin maka kadar air akan semakin tinggi karena penyerapan air yang lebih banyak. Hal ini dapat terjadi kerena adanya proses gelatinisasi yang menyebabkan gugus hidroksil menyerap air sehingga terjadi pembekakan granula pati (Sobukola et al. 2018). Amilopektin merangsang proses terjadinya pembekakan pada produk sehingga produk yang dihasilkan renyah (TrujilloAgudelo et al. 2019).

\section{KESIMPULAN}

Metode pre-heating dan penambahan edible coating dapat meningkatkan kualitas keripik kentang yang dibuat dari umbi kentang varietas granola. Keripik kentang yang paling renyah ditunjukkan dengan nilai hardness yang paling rendah diperoleh dari keripik kentang dengan perlakuan perebusan waktu 4 menit. Hasil uji sensori juga menunjukan bahwa keripik kentang dengan perlakuan perebusan waktu 4 menit memiliki nilai skoring kerenyahan dan hedonik keseluruhan yang tertinggi yaitu pada level agak suka. Penggunaan acacia gum sebagai edible coating dan penambahan kalsium klorida pada pembuatan kripik kentang dapat mengurangi kadar lemak dan penyerapan minyak selama penggorengan. Keripik kentang dengan penambahan konsentrasi acacia gum 5\% dan kalsium klorida 1\% mempunyai kadar lemak dan penyerapan minyak yang paling rendah dengan nilai $28.01 \pm 1.56$ dan $-41.81 \pm 5.86 \%$ diikuti dengan rasio penyerapan minyak yang terendah juga sebesar $0.32 \pm 0.03$. Kadar amilosa dan amilopektin yang tertinggi dihasilkan pada keripik kentang tanpa penambahan acacia gum $0 \%$, sedangkan yang terendah dengan penambahan acacia gum $6 \%$.

\section{DAFTAR PUSTAKA}

Ajo RY. 2017. Application of hydrocolloids as coating films to reduce oil absorption in fried potato chipbased pellets. Pakistan J Nutr 16 (10): 805-812. DOI: 10.3923/pjn.2017.805.812.

Anugrahati NA, Pranoto Y, Marsono Y, Marseno D. 2015. In vitro digestibility of Indonesian cooked rice treated with cooling-reheating process and coconut milk addition. Int Res J Biol Sci 4 (12): 34-39.

Angor MM. 2016. Reducing fat content of fried potato pellet chips using carboxymethyl cellulose and soy protein isolate solutions as coating films. J Agric Sci 8 (3): 162-169. DOI: 10.5539/jas.v8n3p162.

[AOAC] Association of Official Analytical Chemists. 2005. Official Methods of Analysis, Association of Official Analytical Chemists, 13th Edition, PO Box NO540, Benjamin Franklin Station, Washington DC.

Arum RH, Dewayani W, Syamsuri R, Septianti E. 2021. Pengaruh jenis dan konsentrasi bahan perendam terhadap mutu keripik kentang varietas super john. J Pengkajian Pengembangan Teknol Pertanian 24(1): 55-65. DOI: 10.21082/jpptp.v24n1.2021.p55-65.

Asgar A. 2013. Kualitas umbi beberapa klon kentang (Solanum tuberosum L.) dataran medium untuk keripik. Berita Biologi 12 (1): 29-37. DOI: 10.142 03/beritabiologi.v12i1.515.

Beals KA. 2019. Potatoes, nutrition and health. Am J Potato Res 96(2019): 102-110.

[BSN] Badan Standardisasi Nasional. 1996. SNI 014031-1996 - Keripik Kentang. Jakarta: Badan Standardisasi Nasional.

Caetano PK, Mariano-Nasser FAC, Mendonca VZ, Furlaneto KA, Daiuto ER, Vieites RL. 2017. Physicochemical and sensory characteristics of sweet potato chips undergoing different cooking methods. Food Sci Technol (38)3: 434-440. DOI: 10.1590/ 1678-457X.08217.

Chandra L, Marsono Y, Sutedja AM. 2014. Sifat fisikokimia dan organoleptik flake beras merah dengan variasi suhu perebusan dan suhu pengeringan. J Teknol Pangan Gizi 13 (2): 57-68. 
Damto E, Chala G. 2019. Effect of blanching and frying time on the sensory quality of fried sweet potato chips. Food Nutr Sci 3 (2019): 1-17 DOI: 10.13140/ RG.2.2.27930.08647.

Direktorat Jenderal Hortikultura. 2019. Swasembada Kentang. Kementerian Pertanian Republik Indonesia 526/R-KEMENTAN/07/2019. Jakarta: Kementerian Pertanian Republik Indonesia.

Fajiarningsih H. 2013. Pengaruh Penggunaan Komposit Tepung Kentang (Solanum tubesorum L) terhadap Kualitas Cookies. [Skripsi]. Semarang: Fakultas Teknik, Universitas Negeri Semarang.

Falguera V, Quintero J, Jiménez A, Muñoz J, Ibarz A. 2011. Edible films and coatings: Structures, active functions and trends in their use. Trends Food Sci Tech 22(6): 292-303. DOI: 10.1016/j.tifs.2011.02. 004.

Grizotto R, De Menezes HC. 2020. Effect of cooking on the crispness of cassava chips. J Food Sci 67(3): 1219-1223. DOI: 10.1111/j.1365-2621.2002.tb0948 $0 . x$.

Haryanti P, Sustriawan B, Sujiman. 2013. Perendaman dalam kalsium klorida dan penggunaan edible coating untuk meningkatkan kualitas french fries dari kentang varietas tenggo dan krespo. Agritech 33 (1): 38-45.

Hua X, Wang K, Yang R, Kang J, Yang H. 2015. Edible coatings from sunflower head pectin to reduce lipid uptake in fried potato chips. LWT-Food Sci Technol 62(2): 1220-1225. DOI: 10.1016/j.lwt.2015.02.010.

Kurek M, Šcetar M, Galic K. 2017. Edible coatings minimize fat uptake in deep fat fried products: A review. Food Hydrocolloids 71(2017): 225-235. DOI: 10.1016/j.foodhyd.2017.05.006.

Listianti R, Ediati R. 2019. Pengaruh Persentase dan Lama Perendaman Dalam Air Panas dan Larutan Kapur Terhadap Kualitas Keripik Kentang Varietas Granola. Prosiding Seminar Nasional Pengembangan Sumber Daya Perdesaan dan Kearifan Lokal Berkelanjutan IX: 211, 19- 20 November 2019. Universitas Jenderal Soedirman, Purwokerto.

Maity T, Bawa AS, Raju PS. 2015. Use of hydrocolloids to improve the quality of vacuum fried jackfruit chips. Int Food Res J 22 (4): 1571-1577. DOI: 10. 1016/j.foodres.2004.04.009.

Magre JB, Gawande SB, Nerker PP, Patil ID. 2019. Effect of hydrocolloids on oil uptake in Bhature. Int J Manag Technol Eng 9(1): 1182-1188.

Mandei JH, Nuryadi AM. 2017. Pengaruh cara perendaman dan jenis kentang terhadap mutu keripik kentang. J Penelitian Teknol Industri 9(2): 123-136. DOI: 10.33749/jpti.v9i2.3516.

Mousa RMA. 2018. Simultaneous inhibition of acrylamide and oil uptake in deep fat fried potato strips using gum Arabic-based coating incorporated with antioxidants extracted from spices. Food Hydro- colloids 83(2018): 265-274. DOI: 10.1016/j.food hyd.2018.05.007.

Niken A, Adepristian D, Sumarno. 2013. Isolasi amilosa dan amilopektin dari pati kentang. J Teknol Kimia Industri 2(3): 57-62.

Prahardini PER, Pratomo G. 2011. Uji Adaptasi Varietas dan Klon Kentang Olahan Pada Musim Kemarau di Dataran Tinggi Beriklim Kering. Balai Pengkajian Teknologi Pertanian Jawa Timur.

Rahmawati WA, Nisa FC. 2015. Fortifikasi kalsium cangkang telur pada pembuatan cookies. J Pangan Agroind 3(3): 1050-1061.

Rosanna, Octora Y, Ahza AB, Syah D. 2015. Prapemanasan meningkatkan kerenyahan keripik singkong dan ubi jalar ungu. J Teknol Industri Pangan 26(1): 72-79. DOI: 10.6066/jtip.2015.26.1.72.1.72.

Sanyang ML, Sapuan SM, Jawaid M, Ishak MR, Sahari J. 2019. Effect of glycerol and sorbitol plasticizers on physical and thermal properties of sugar palm starchbased films. Conference: 13th International Conference on Environment, Ecosystems and Development 2019: 157-162. Kuala Lumpur, Malaysia.

Sobukola P, Dueik V, Bouchon P. 2018. Understanding the effect of vacuum level in structure development and oil absorption in vacuum-fried wheat starch and gluten-based snacks. Food Bioprocess Tech 6(8): 2010-2017. DOI: 10.1007/s11947-012-0899-1.

Tiwari P, Joshi A, Varghese E, Thakur M. 2018. Process standardization and storability of calcium fortified potato chips through vacuum impregnation. J Food Sci Tech 55(8): 3221-3231. DOI: 10.1007/s13197018-3254-3.

Thanatuksorn P, Kajiwara K, Suzuki T. 2018. Characterization of deep-fat frying in a wheat flour-water mixture model using a state diagram. J Sci Food Agric 87(14): 2648-2656. DOI: 10.1002/jsfa. 3027.

Torres-González JD, Alvis-Bermúdez A, Morales JDCJ. 2017. Alternatives to reduce fat uptake during deep fat frying of food. Int $\mathbf{J}$ Adv Res 5 (9): 1-14. DOI: $10.21474 / \mathrm{IJAR01/5501.}$

Trujillo-Agudelo S, Osorio A, Gómez F, ContrerasCalderón J, Mesías-Garcia M, Delgado-Andrade C, Morales F, Vega-Castro O. 2019. Evaluation of the application of an edible coating and different frying temperatures on acrylamide and fat content in potato chips. J Food Process Eng 43(5): 1-11.

[USDA] United States Department of Agriculture National Nutrient Database. 2019. Potato, raw. National Agricultural Library. USA.

Valdés DF, Baños BS, Valdés DF, Ramírez AO, Pereira AG, Rodríguez AF. 2015. Eatable films and coverings: a favorable alternative in the postharvesIng. conservation of fruits and vegetables. Revista Ciencias Técnicas Agropecuarias 24 (3): 52-57. 
Wibowo C, Dwiyanti H, Haryanti P. 2006. Peningkatan kualitas keripik kentang varietas granola dengan metode pengolahan sederhana. J Akta Agrosia 9 (2): 102-109.

Wibowo C, Wicaksono R, Haryanti P. 2018. Effect of sorbitol in application of edible coating on the quality of potato chips. IOP Conference Series: Earth and Environmental Science Vol 250, International Conference on Sustainable Agriculture for Rural Development 2018 (ICSARD 2018) 23-24 October
2018, Purwokerto, Indonesia. DOI: 10. 1088/17551315/250/1/012045.

Wibowo C, Wicaksono R, Erminawati. 2019. Effect of edible coating on quality of chips from potato variety granola. Int J Adv Science Eng Information Technol 8(5): 2099-2105. DOI: 10.18517/ijaseit.8.5. 4331.

JMP-07-21-09-Naskah diterima untuk ditelaah pada 25 Februari 2021. Revisi makalah disetujui untuk dipublikasi pada 5 April 2021. Versi Online: http://journal.ipb.ac.id/index.php/jmpi 